\title{
Determination of abundance and distribution of an intertidal barnacle: settlement or post-settlement mortality?
}

\author{
Carolyn J. Jeffery* \\ Centre for Research on Ecological Impacts of Coastal Cities and Institute of Marine Ecology, Marine Ecology Laboratories, \\ A11, University of Sydney, Sydney, New South Wales 2006, Australia \\ Present address: 13 Rhonda Avenue, Frenchs Forest, Sydney, New South Wales 2086, Australia
}

\begin{abstract}
The honeycomb barnacle Chamaesipho tasmanica Foster and Anderson has great variation in abundance and distribution in intertidal areas at Cape Banks, New South Wales. This study was initiated to explain these observed patterns by investigating the relative effects of settlement and post-settlement mortality on populations of $C$. tasmanica. The relative importance of stages of the life history in determining the demography of adult populations was interpreted by simultaneous studies of adults and of juveniles from July 1989 to July 1994. It was found that settlement was integral to the demography of these barnacles; the alternative model that post-settlement mortality determined the distributions and abundance of juveniles and adults was discounted by experimental tests. Spatial patterns of post-settlement mortality of juveniles did not match spatial patterns of adult mortality. Conversely, despite great post-settlement mortality of juveniles, especially when the limpet Cellana tramoserica was present, spatial patterns of juveniles were retained by adults. Although there were isolated incidences of intense mortality by the whelk Morula marginalba, larval processes primarily determined the numbers of $C$. tasmanica at Cape Banks. Moreover, recruitment each year was not sufficient to maintain populations of adult barnacles; hence, numbers at Cape Banks were observed to decrease from 1989 to 1993 at all sites and heights studied. This study therefore emphasized the importance of the juvenile stage in maintaining populations of C. tasmanica.
\end{abstract}

KEY WORDS: Barnacles · Chamaesipho tasmanica $\cdot$ Settlement $\cdot$ Cellana tramoserica $\cdot$ Post-settlement mortality $\cdot$ Intertidal

Resale or republication not permitted without written consent of the publisher

\section{INTRODUCTION}

Early ecological studies emphasized the adult stage when attempting to explain patterns of abundance and distribution of intertidal marine assemblages (Connell 1961a,b, 1970, Paine 1969, 1974, Dayton 1971). Physical factors such as temperature and desiccation were considered to determine the upper limits of vertical distribution and caused fluctuations of densities within these populations (Connell 1961a,b, 1975, Brown 1967 , Vermeij 1971). Biological factors such as competition and predation were said to determine the lower limits and also influenced population densities (Con- nell 1961a,b, Dayton 1971, Menge 1976, Paine 1974, 1984, Menge \& Sutherland 1976).

In the $1970 \mathrm{~s}$, several studies confirmed that the post-settlement mechanisms of predation and disturbance could operate to maintain local diversity of intertidal species (Paine 1974, Lubchenco 1978, Sousa 1979, Menge \& Lubchenco 1981). Experimental studies on intertidal rocky shores in North America showed that predation (Paine 1966, 1974, Connell 1972, Gaines \& Roughgarden 1985), grazing (Lubchenco 1978, 1980) and physical disturbances (Dayton 1971) cause mortality and maintain relatively small densities while opening space for new 
recruits and influencing diversity of species (Valiela 1984).

The role of predation and disturbance as a general model for promoting diversity of species was largely unchallenged until Underwood et al. (1983) found that the abundance of various species in several rocky intertidal areas in New South Wales, Australia was determined by the number of recruits. That is, patterns of distribution could also be due to processes of settlement or recruitment. Other studies support this association of larval settlement and species distribution (e.g. Denley \& Underwood 1979, Grosberg 1982, Gaines \& Roughgarden 1985, Minchinton \& Scheibling 1991).

Hence, for more than the past decade, there has been controversy about the relative importance of juvenile and adult stages in processes causing distributions of populations in sessile marine invertebrates (e.g. Denley \& Underwood 1979, Underwood \& Denley 1984, Connell 1985). Connell (1985) emphasized the effects of post-settlement mortality on survival and ultimate distributions of adult barnacles, whereas Underwood \& Denley (1984) highlighted mechanisms influencing settlement and recruitment of larvae. More recent studies have reinforced that settlement processes, such as larval supply and larval choice (Raimondi 1991), determine recruitment and the demography of adults (Carroll 1996, Miron et al. 1999, Menge 2000, Olivier et al. 2000), although early post-settlement mortality (for review see Hunt \& Scheibling 1997) may also be implicated (Carroll 1996, Miron et al. 1999, Jenkins et al. 2000, Menge 2000).

Nevertheless, there have been very few simultaneous studies of larval supply, settlement, recruitment and adult barnacles (but see review Roughgarden et al. 1988, Ross 1992, Carroll 1996, Jeffery 1997, Miron et al. 1999, Olivier et al. 2000). Yet any stage of the life history may influence spatial patterns of adults. The intertidal honeycomb barnacle Chamaesipho tasmanica varies greatly from crowded to patchy to sparse aggregations within small spatial scales on mid-shores at Cape Banks, New South Wales. This study examined juveniles and adults to clarify the relative importance of settlement versus post-settlement processes on populations of these barnacles.

Initial settlement (larval supply and larval choice) (Raimondi 1991) determines distributions of juvenile Chamaesipho tasmanica (Jeffery 2000, Jeffery \& Underwood 2000). Hence, numbers of newly settled barnacles could be related to ultimate abundances of adults. It was therefore necessary to examine the model that settlement processes determine adult distributions of this barnacle. That is, it was hypothesized that if newly settled barnacles were monitored, similar spatial patterns would be maintained through time while barnacles grew to adulthood, despite the effects of mortality. It was also hypothesized that if adults and total numbers of new settlers were counted each year at 6 sites (for details on all 6 sites see Jeffery \& Underwood 2001) at Cape Banks, similar spatial patterns of abundance of settlers and subsequent adults at these sites would confirm that settlement influences distribution and abundance of adult C. tasmanica.

Alternatively, processes acting after cyprids settle and metamorphose may determine distributions of Chamaesipho tasmanica. That is, post-settlement mortality of juveniles and/or adult mortality may affect the abundance and distribution of populations. It was therefore necessary to examine the alternative model that post-settlement mortality determines juvenile and/or adult spatial distributions of C. tasmanica at Cape Banks. Fewer barnacles were observed on upper and more exposed shores at Cape Banks. Differences in post-settlement and adult mortality in these areas could contribute to these patterns. It was therefore postulated that if numbers of juvenile and adult C. tasmanica surviving over time were counted, greater mortality of juvenile and adult barnacles on exposed and upper shores would determine that fewer barnacles inhabited these areas. That is, it was predicted that spatial patterns of mortality of juvenile and adult barnacles would reflect the spatial patterns of juveniles and adults at Cape Banks.

Limpets can affect survival and densities of barnacles after settlement (e.g. Connell 1961b, Dayton 1971, Underwood 1979, Branch 1981, Farrell 1988). The limpet Cellana tramoserica is abundant on sheltered mid-shore heights on rocky shores in New South Wales (Underwood et al. 1983) and can influence survival of juvenile barnacles (Denley \& Underwood 1979, Caffey 1983, Underwood et al. 1983). Early in this study, $C$. tramoserica was observed in greater numbers on lower mid-shores within distributions of Chamaesipho tasmanica at the sheltered Sites 3 and 4 at Cape Banks. Hence, C. tramoserica could be contributing to adult patterns of distribution of C. tasmanica by killing new settlers. It was therefore hypothesized that if new settlers of $C$. tasmanica were exposed to limpets in some patches but not in others, there should be a significantly reduced survival of barnacles in patches with limpets. That is, the presence of limpets would influence juvenile mortality and, possibly, the distributions of adults.

The hypotheses listed above were tested to determine the relative importance of settlement and postsettlement processes on populations of the barnacle Chamaesipho tasmanica at Cape Banks. 


\section{MATERIALS AND METHODS}

Study site. Chamaesipho tasmanica were studied from July 1989 to December 1993 on mid-shore levels of the Cape Banks Scientific Marine Research Area, Botany Bay, New South Wales $\left(34^{\circ} 00^{\prime} \mathrm{S}, 150^{\circ} 15^{\prime} \mathrm{E}\right)$, Australia. Barnacles were studied at 6 sites (for details of Sites 1 to 6 see Jeffery \& Underwood 2001) and on 3 heights (Low, Mid, Upper-for details see Jeffery \& Underwood 2001) determined by the distribution of this barnacle at each site. C. tasmanica are often densely distributed on sheltered (Sites 3 and 4) and lower mid-shores and sparsely distributed on exposed (Sites 1, 2 and 6), semi-exposed (Site 5) and upper mid-shores (Underwood 1981a, Underwood \& Denley 1984).

Settlement involves attachment and metamorphosis of cyprid larvae (Underwood 1979, Underwood \& Denley 1984, Connell 1985). Settlement in Chamaesipho tasmanica includes the cyprid stage that lasts for less than 1 day, the 2 to 3 day 6 plate metamorph stage and the less than 4 day 4 plate juvenile stage (Jeffery 1997).
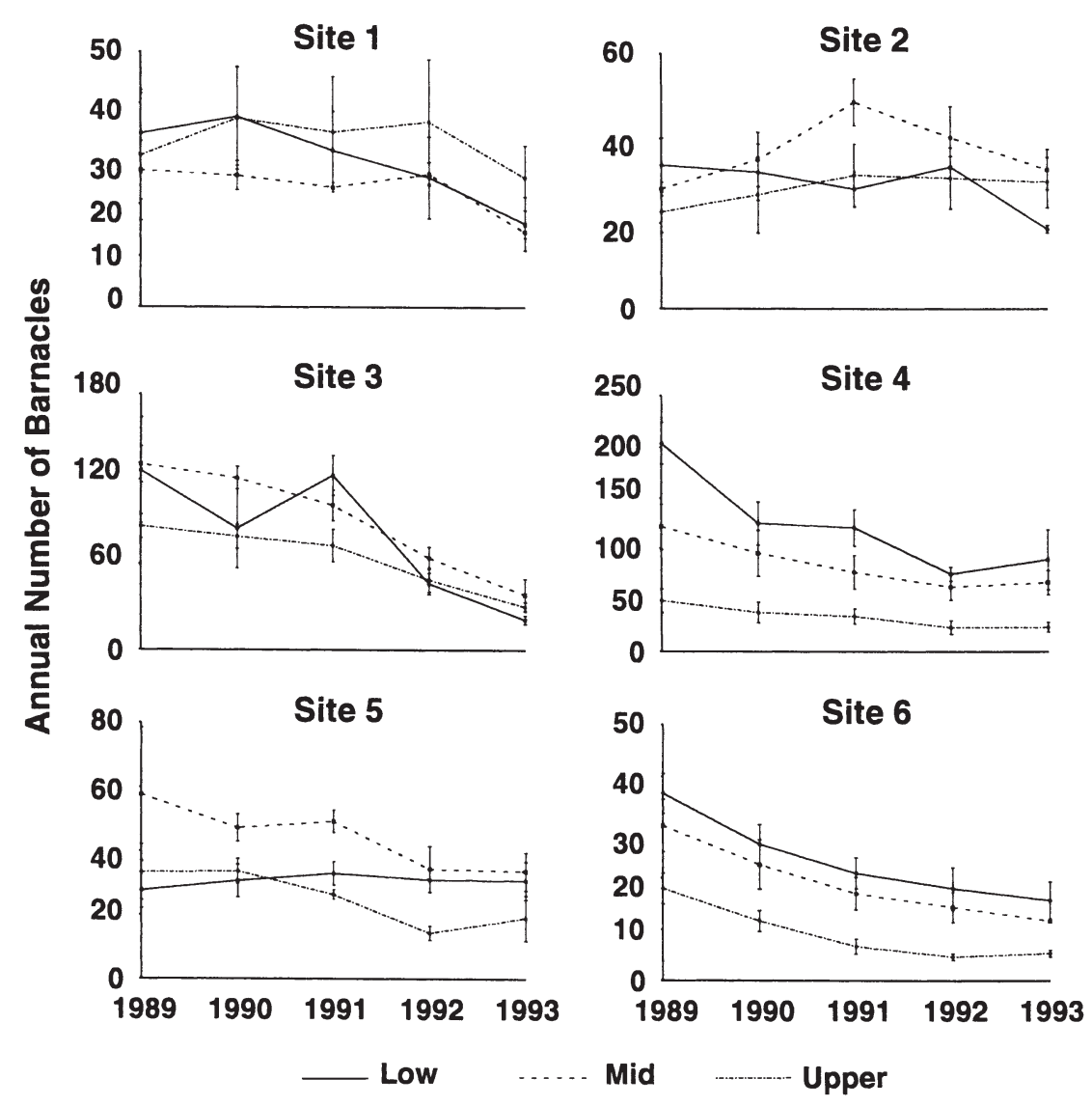

Fig. 1. Chamaesipho tasmanica. Mean total number of barnacles $( \pm \mathrm{SE})$ in $6 \mathrm{~cm}$ diameter replicates $(n=3)$ at 3 heights at the 6 sites from the end of 1989 to the end of 1993
Table 1. Chamaesipho tasmanica. Analysis of numbers of mixed cohorts of adult barnacles $(\mathrm{n}=3)$ at Low, Mid and Upper heights of C. tasmanica's distribution on the shore at 6 sites: data are from the end of each year from 1989 to 1993. ns: $\mathrm{p}>0.05{ }^{*} \mathrm{p}<0.05{ }^{* *} \mathrm{p}<0.01{ }^{* * *} \mathrm{p}<0.001$

\begin{tabular}{|lrrrc|}
\hline \multicolumn{5}{l}{ Analysis of variance, data transformed $(x+1)^{0.5} ;$} \\
Cochran's test, $\mathrm{p}>0.05$ \\
Source & df & \multicolumn{1}{l}{ MS } & \multicolumn{1}{l}{$F$} & $\mathrm{p}$ \\
\hline Time $=\mathrm{T}$ & 4 & 37.98 & 5.75 & ${ }^{* *}$ \\
$\mathrm{Site}=\mathrm{S}$ & 5 & 152.78 & 115.67 & ${ }^{* * *}$ \\
$\mathrm{Height}=\mathrm{H}$ & 2 & 50.58 & 2.96 & $\mathrm{~ns}$ \\
$\mathrm{~T} \times \mathrm{S}$ & 20 & 6.61 & 5.00 & ${ }^{* * *}$ \\
$\mathrm{~T} \times \mathrm{H}$ & 8 & 1.12 & 1.30 & $\mathrm{~ns}$ \\
$\mathrm{~S} \times \mathrm{H}$ & 10 & 17.11 & 12.95 & ${ }^{* * *}$ \\
$\mathrm{~T} \times \mathrm{S} \times \mathrm{H}$ & 40 & 0.86 & 0.65 & $\mathrm{~ns}$ \\
Residual & 180 & 1.32 & & \\
\hline
\end{tabular}

Abundance and distribution. In July 1989, $6 \mathrm{~cm}$ diameter replicates $(n=3)$ of mixed cohorts of barnacles were marked with an inscribed metal tag cemented into the substratum at all 6 sites and 3 heights of Chamaesipho tasmanica's distribution on mid-shore levels at Cape Banks. In December of each year from 1989 to 1993, these replicates were photographed in the field with a $35 \mathrm{~mm}$ camera attached to a $26 \mathrm{~cm}$ high brass tripod. Populations of barnacles were mapped from black-and-white negatives in the laboratory (for all details see Jeffery \& Underwood 2001), so that at the end of each year, new or missing barnacles could be recorded. Numbers of mixed cohorts of barnacles were recorded in December each year from 1989 to 1993.

Distributions of settlers and adults at 6 sites. From July to December of each year from 1989 to 1993, numbers of new settlers among mixed cohorts of adults in untouched $6 \mathrm{~cm}$ diameter replicates $(n=3)$, labeled with an inscribed metal tag, were counted for approximately 6 consecutive days during each new and full moon to coincide with larval arrival and settlement (Jeffery \& Underwood 2000) at the 6 sites and 3 heights of Chamaesipho tasmanica's distribution. In each lunar sampling period, numbers were recorded at each height and site, then totaled for each year and total numbers of settlers analyzed to determine spatial patterns of settlement. These patterns were compared with adult spatial patterns at 6 sites and 3 heights from 1989 to 1993 (Figs. 1 \& 2, Tables 1 \& 2). 


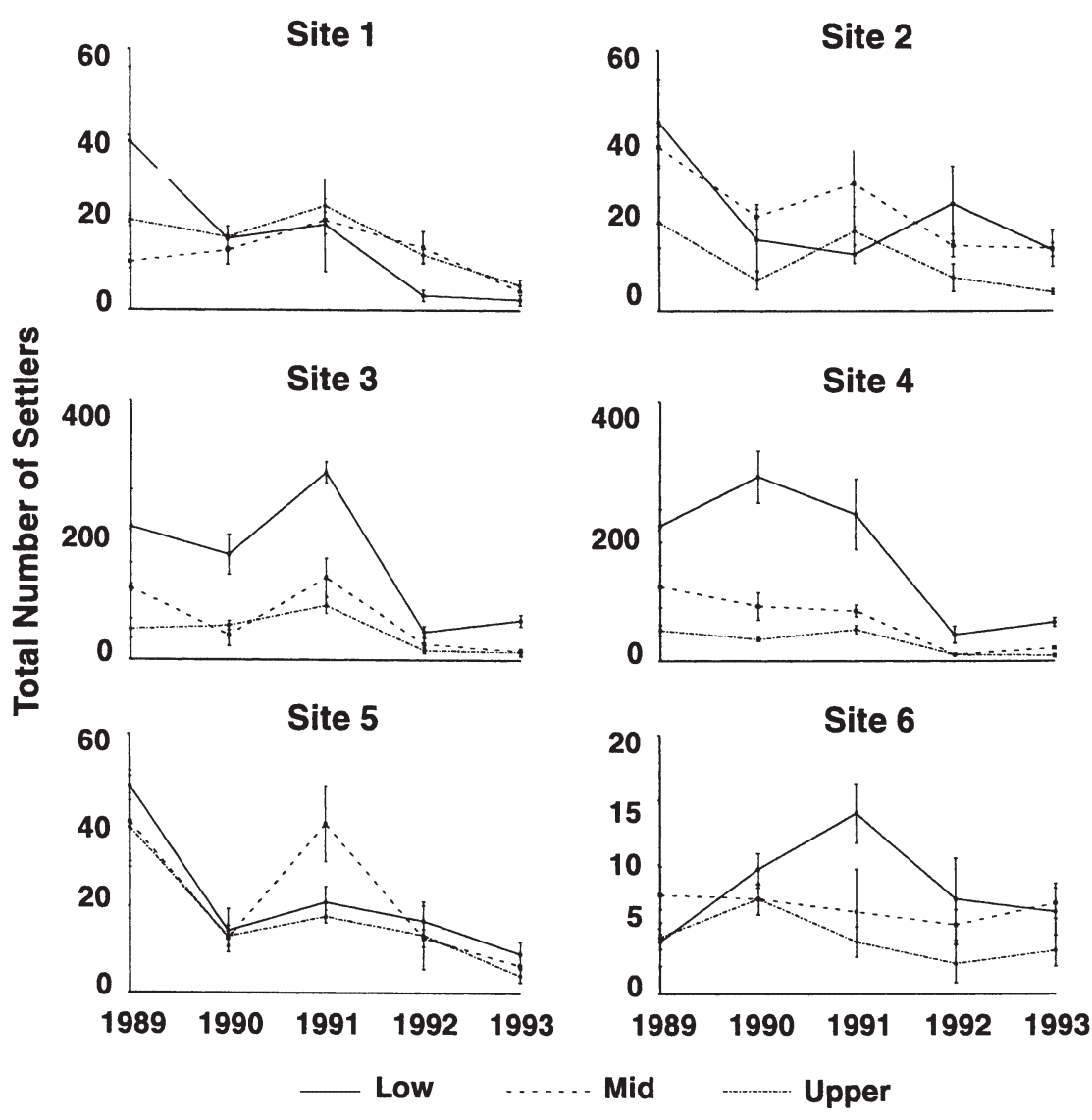

Fig. 2. Chamaesipho tasmanica. Mean total number of settlers $( \pm \mathrm{SE})$ in $6 \mathrm{~cm}$ diameter replicates $(n=3)$ recorded from July to December each year from 1989 to 1993 at 3 heights at the 6 sites

Juvenile and adult mortality. To standardize data from different sites and heights, percentage mortality was analyzed. Annual mortality of adults was estimated in late October or November each year from

Table 2. Chamaesipho tasmanica. Analysis of total numbers of settlers $(\mathrm{n}=3)$ each year at Low, Mid and Upper heights of $C$. tasmanica's distribution on the shore at 6 sites: data are total number of settlers at the end of each year from 1989 to 1993. ns: $p>0.05 ;{ }^{*} \mathrm{p}<0.05{ }^{* *} \mathrm{p}<0.01{ }^{*}{ }^{* * *} \mathrm{p}<0.001$

\begin{tabular}{|c|c|c|c|c|}
\hline Source & df & MS & $F$ & $\mathrm{p}$ \\
\hline Time $=\mathrm{T}$ & 4 & 17.58 & 12.33 & $* * *$ \\
\hline Site $=\mathrm{S}$ & 5 & 30.33 & 123.31 & $* * *$ \\
\hline Height = H & 2 & 11.09 & 4.34 & ${ }^{*}$ \\
\hline $\mathrm{T} \times \mathrm{S}$ & 20 & 1.42 & 5.79 & $* * *$ \\
\hline $\mathrm{T} \times \mathrm{H}$ & 8 & 0.12 & 0.35 & ns \\
\hline $\mathrm{S} \times \mathrm{H}$ & 10 & 2.56 & 10.40 & $* * *$ \\
\hline $\mathrm{T} \times \mathrm{S} \times \mathrm{H}$ & 40 & 0.33 & 1.35 & ns \\
\hline Residual & 180 & 0.25 & & \\
\hline
\end{tabular}

1990 to 1992 , as the percentage of adults lost from the initial population recorded 12 mo previously. Because settlement occurred from August to December, percentage mortality of new settlers was estimated on cumulative settlement for this period, rather than annually, from 1989 to 1993. Mortalities of adults and juveniles were analyzed for 6 sites and 3 heights of Chamaesipho tasmanica's distribution.

To test the hypothesis that mortality would increase when large densities and percent cover predominated (that is, mortality of Chamaesipho tasmanica was predicted to be density-dependent or cover-dependent), correlations were calculated on pooled means $(n=3)$ of C. tasmanica's distribution from 1990 to 1992 for adults and from 1989 to 1993 for total settlers for all 6 sites and 3 heights. For adults, relationships of annual percentage mortality between initial density of adults and between initial percent cover were analyzed. For settlers, relationships of percentage mortality between cumulative density of settlers and between initial percent cover were analyzed. Because barnacles inhabit higher levels on ex-posed shores with more wave-action (Underwood 1981a), greater mortality was expected in these areas. Therefore, comparisons between percentage mortality of juveniles and of adults were made by analyzing data from 3 heights of $C$. tasmanica's distribution at 6 sites from 1990 to 1992. Relationships were also calculated between total numbers of barnacles that settled at each site and the final numbers of settlers that remained in December in each site each year from 1989 to 1993.

Effect of Cellana tramoserica. In July 1990 and 1991, 6 cm diameter patches were cleared within dense populations of Chamaesipho tasmanica low on the shore of C. tasmanica's distribution at Sites 3 and 4. Settlers in cleared patches were counted on 6 to 8 consecutive days, with weather, tide and time permitting, during new and full moons from July to December 1990 and 1991. In November each year, once most settlement had occurred, the limpet $C$. tramoserica was added to $1 / 2$ these patches and excluded from the rest.

As an extra precaution, fences were incorporated in the experimental design to exclude any grazers other than the limpet Cellana tramoserica, such as the snail 
Nerita atramentosa and the limpets Siphonaria denticulata and Patelloida latistrigata. To determine the effects of fences (Underwood \& Jernakoff 1984, Hancock \& Petraitis 2001) on settlement and to discount the possibility that ungrazed spores of macroalgae such as Ulva lactuca may grow and pre-empt space during settlement (Denley \& Underwood 1979, Underwood \& Denley 1984), $1 / 2$ the cleared patches on the substratum were left unfenced. Any other species of grazers that ventured into these plots were removed daily because their presence could confound experiments in unfenced areas where grazers were meant to be absent. Because fewer other barnacles, such as Tesseropora rosea and Tetraclitella purpurascens, were found to settle in areas surrounded by experimental fences (Denley \& Underwood 1979, Underwood \& Denley 1984), fences were only secured to the substratum in November 1990 and 1991, once most settlement had occurred. The limpet C. tramoserica was also first included in $50 \%$ of patches at this time. Homing behavior in C. tramoserica has already been demonstrated (Mackay \& Underwood 1977, Underwood 1977, 1988). If variations in numbers of limpets occurred in experimental treatments, however, these numbers were corrected daily over each 6 to $8 \mathrm{~d}$ sampling period by adding or removing limpets.

On 14 November 1990 and 18 November 1991, fences $(6$ meshes per $2.5 \mathrm{~cm}$ : $20 \times 20 \times 4 \mathrm{~cm}$ ) were secured around $50 \%$ of the $6 \mathrm{~cm}$ diameter plots, containing Chamaesipho tasmanica that had settled since July $(\mathrm{n}=4)$, with screws in rawl plugs and lead $(\mathrm{Pb})$ washers. Half the treatments were left unfenced to act as controls for the effect of fences, and for possible toxicological effects of lead $(\mathrm{Pb})$, at the 2 sites. Three Cellana tramoserica, equivalent to the observed density of $C$. tramoserica in natural patches among C. tasmanica, were placed in $50 \%$ of the $6 \mathrm{~cm}$ diameter patches containing established juveniles $(\mathrm{n}=4)$. About 6 wk later each year, on 27 December 1990 and 6 January 1992, respectively, percentage mortality of settlers was estimated from the numbers that had established prior to adding any limpets plus any new barnacles that settled in the interim.

From December each year, numbers of remaining barnacles were counted monthly and any new settlers were recorded. About 6 mo later, in late June 1991 and early July 1992, fences and Cellana tramoserica were removed. Because densities of settling barnacles vary at very small spatial scales (e.g. within $2 \mathrm{~cm}$ ) percentage mortality was used to standardize data. From April to July 1992, the whelk Morula marginalba invaded all replicates in Site 3 and caused mortality of C. tasmanica.

Data analysis. Three-factor ANOVAs (Underwood $1981 b, 1997)$ were used to examine numbers of adult barnacles that occupied the 6 sites and 3 heights of Chamaesipho tasmanica's distribution from the end of each year from 1989 to 1993. Data on total numbers of barnacles that settled from August to December each year from 1989 to 1993 were similarly treated. Data for numbers of adults and for total settlement recorded each year were transformed by $(x+1)^{0.5}$ and $\log _{\mathrm{e}}(x+1)$, respectively, to correct for heterogeneity of variances as detected by Cochran's test. Post hoc multiple comparison tests were done on transformed data with Student-Newman-Keuls (SNK) tests (Underwood 1997) to test for differences of means among factors.

Percentage mortality of settlers was calculated on cumulative density from settlement in August to December each year from 1989 to 1993, whereas annual percentage mortality of adults was estimated at the end of each year from 1990 to 1992 as a percentage of adults lost from the initial population recorded 12 mo previously. Three-factor ANOVAs (Underwood $1981 b, 1997)$ were used to determine whether mortality varied among the 6 sites and 3 heights of Chamaesipho tasmanica's distribution for adults from the end of each year from 1990 to 1992 and for settlers from 1989 to 1993. An additional 4-factor ANOVA (Underwood 1981b, 1997) was used to compare juvenile and adult percentage mortality from 1990 to 1992. Data were arcsine (\%) transformed for each analysis, but transformation could not stabilize variances. Post hoc multiple comparison tests were done on these untransformed data with SNK tests (Underwood 1997) to test for differences of means among factors.

Linear correlations $(r)$ were used to determine the relationships between annual percentage mortality of adults from 1990 to 1992 and (1) height on the shore, (2) initial adult density and (3) initial percent cover of adults. Linear correlations were also used to determine the relationships between percentage post-settlement mortality of total settlers from 1989 to 1993 and (1) height on the shore, (2) cumulative density of settlers and (3) initial percent cover of surrounding mixed cohorts.

A 4-factor ANOVA (Underwood 1981b, 1997) was used to examine the influence of the presence or absence of the limpet Cellana tramoserica in fenced or unfenced plots on post-settlement mortality of juvenile Chamaesipho tasmanica at Sites 3 and 4 over approximately $6 \mathrm{wk}$ in late 1990 and 1991. Because there was no significant effect of fences on mortality of barnacles, fenced and unfenced data were pooled and reanalyzed. Data were arcsine (\%) transformed for each analysis, but transformation could not stabilize variances. Post hoc multiple comparison tests were done on these untransformed data with SNK tests (Underwood 1997) to test for differences of means among factors. 


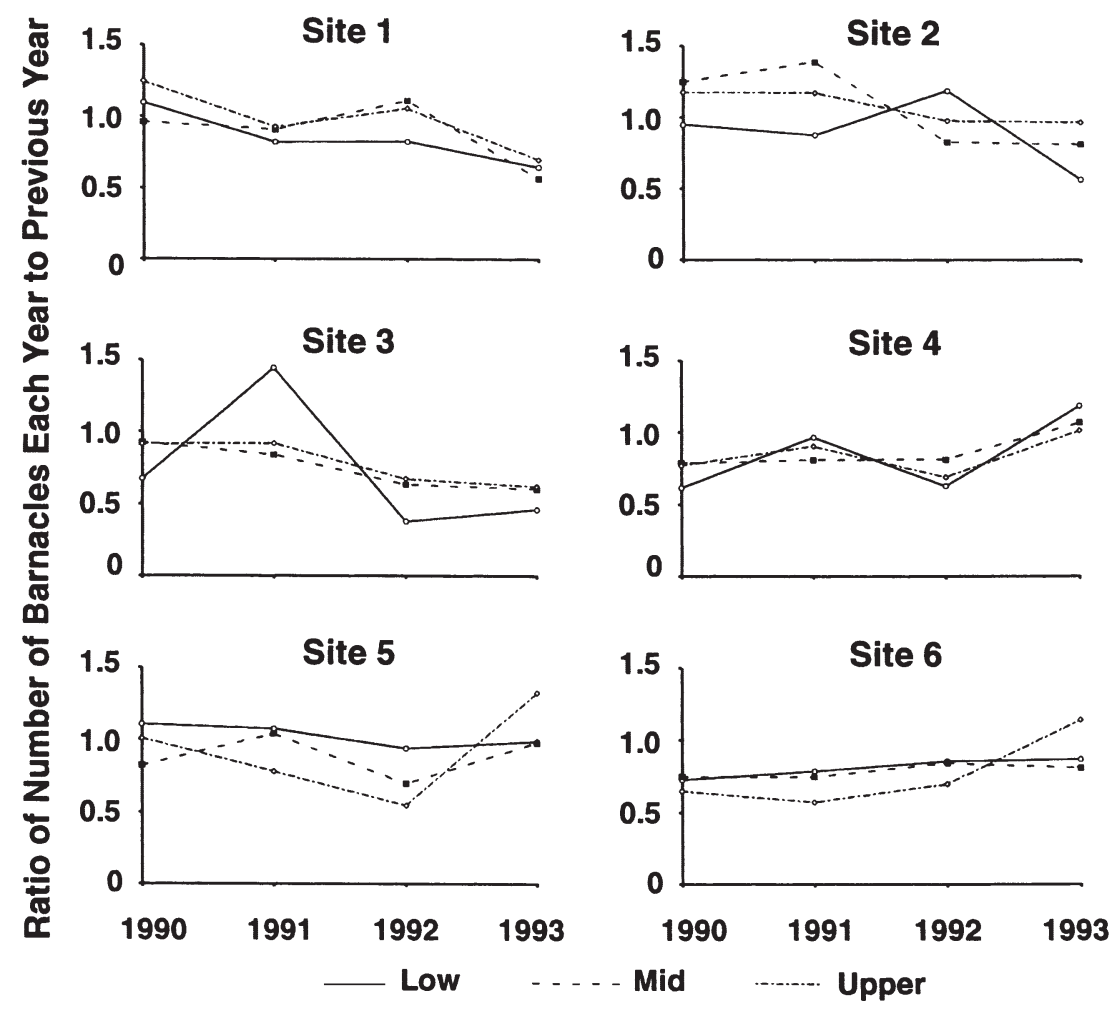

Fig. 3. Chamaesipho tasmanica. Renewal of barnacle distribution in $6 \mathrm{~cm}$ diameter replicates $(n=3)$ at 3 heights at the 6 sites each year from the end of 1989 to the end of 1993: numbers of barnacles recorded for each year were divided by the number of barnacles recorded in the previous year

\section{Settlement and adult distribution}

Distributions of settlers and adults at 6 sites

Spatial and temporal variation in total numbers of settlers occurred from 1989 to 1993 at 6 sites and 3 heights of Chamaesipho tasmanica's distribution studied at Cape Banks (Fig. 2, Table 2). Interactions occurred among Times and Sites and among Sites and Heights (Table 2). Generally barnacles settled in greatest densities in 1989 and in least numbers in 1993. Most barnacles always settled at Sites 3 and 4 and the smallest numbers generally settled at Site 6 (Fig. 2, Table 2). That is, most settlement was recorded on sheltered shores and least on exposed shores. At sheltered Sites 3 and 4, most barnacles settled low on the shore, whereas at the more exposed Sites 1, 2, 5 and 6, there was no real difference among heights although at Sites 2 and 6, total numbers of settlers were similar at Low and Mid heights, which were greater than numbers that settled on Upper heights (Fig. 2, Table 2). Spatial patterns of juveniles (Site $3=$ $4>5=2>1>6$ ) (Fig. 2, Table 2) that settled among mixed cohorts of adults were similar to spatial patterns of these adults (Site $3=4>5=2=1>6$ ) (Fig. 1, Table 1) that were already established

\section{RESULTS}

\section{Abundance and distribution}

Spatial and temporal variations in numbers of mixed cohorts of adults occurred from 1989 to 1993 at Cape Banks (Fig. 1, Table 1). There were interactions among Times and Sites and among Sites and Heights (Table 1). Greatest densities were recorded at sheltered Sites 3 and 4 and least at exposed Site 6 (Fig. 1). Generally, most adults were counted in 1989. Sites with least abundance of barnacles had no significant differences in numbers of barnacles recorded each year from 1989 to 1993. At Site 6, however, there were some differences among years. Most adults generally occurred on Low heights and least adults on Upper heights of Chamaesipho tasmanica's distribution, although there were some differences among Sites (Fig. 1, Table 1). Recruitment each year was generally not sufficient to maintain densities of C. tasmanica except at Site 4 (Fig. 3); therefore, populations at Cape Banks were mostly observed to decrease from 1989 to 1993 (Figs. 1 \& 3). on the substratum. When data from the 6 sites and 3 heights of C. tasmanica's distribution were pooled from 1989 to 1993, there was a strong relationship between annual numbers of settlers and annual numbers of adults (Fig. 4).

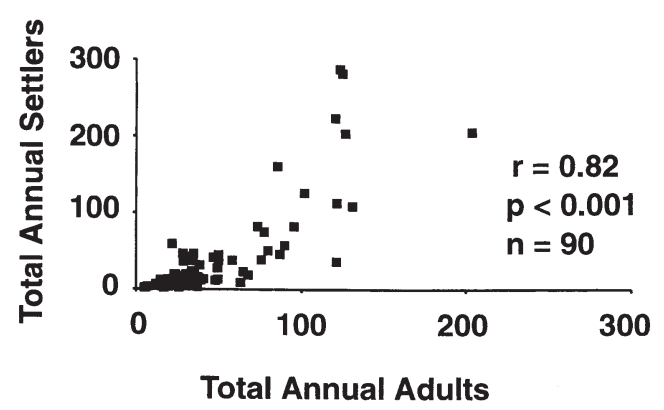

Fig. 4. Chamaesipho tasmanica. Relationship between annual total number of settlers and annual total number of adults $(n=3)$. Each point represents the mean total number of larvae settling in three $6 \mathrm{~cm}$ diameter replicates and the mean total number of adult barnacles already populating these replicates at 3 heights at the 6 sites from 1989 to 1993 

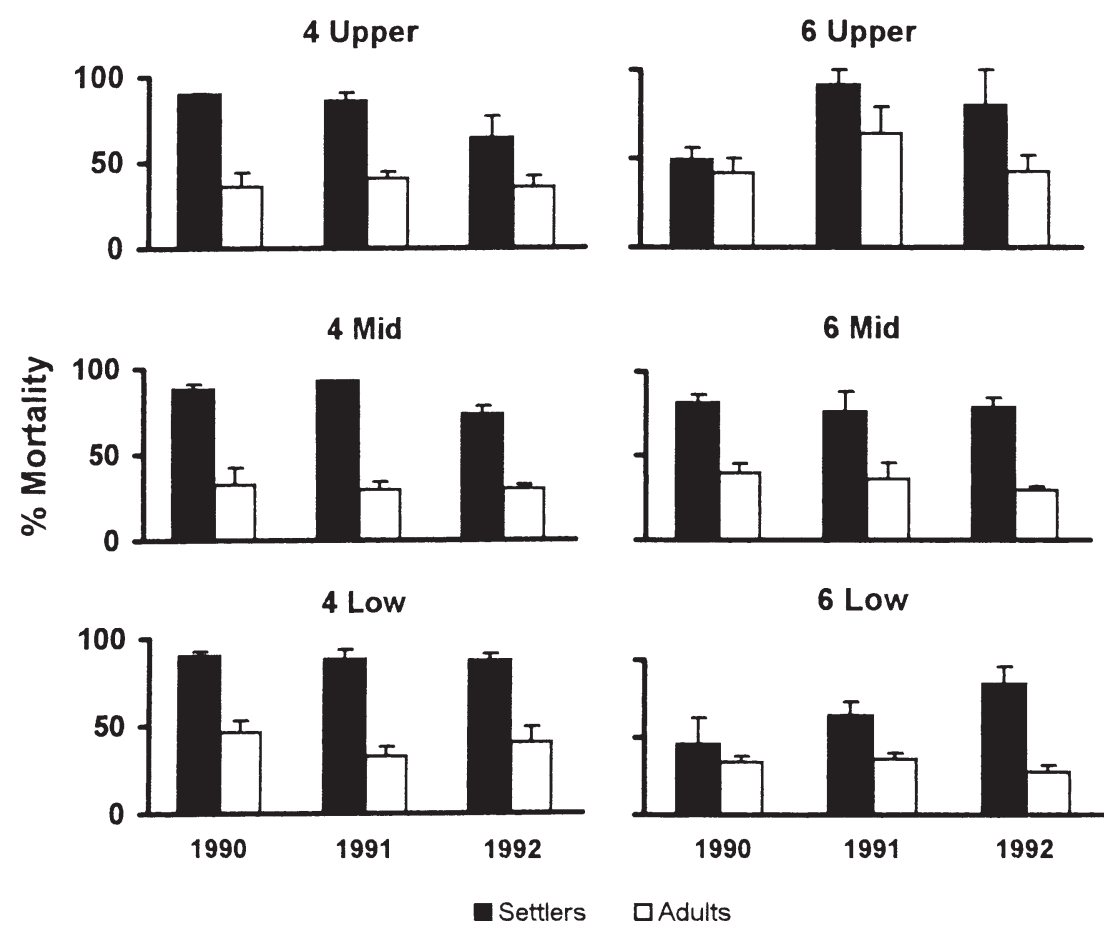

Fig. 5. Chamaesipho tasmanica. Mean annual percentage mortality of mixed cohorts of adults $( \pm \mathrm{SE})$ and mean percentage mortality from August to December of settlers $( \pm \mathrm{SE})$ in $6 \mathrm{~cm}$ diameter replicates $(n=3)$ at 3 heights at sheltered Site 4 and exposed Site 6 from 1990 to 1992

\section{Post-settlement mortality and distribution of adults}

Juvenile and adult mortality

Annual percentage mortality of adults did not vary with height from 1990 to $1992(\mathrm{r}=0.26, \mathrm{p}=0.06$, $\mathrm{n}=54)$. There were, however, interactions among Sites and Times and among Sites and Heights (Table 3). That is, some temporal and spatial variation in adult mortality occurred at Cape Banks from 1990 to 1992, and results were not spatially or temporally consistent (Fig. 5, Table 3). For example, at the end of 1990, Site 2 had most mortality even though there was no significant difference among sites. At the end of 1991 and 1992, when Site 3 had the greatest adult mortality, there was no significant difference among sites although there were some significant differences between those sites that had the greatest and those that had the least percentage mortalities (Table 3).

At Low heights, Site 3 had most mortality of adults and there were no significant differences among other sites. At Mid heights, mortality of adults was similar for all sites with Site 5 having the greatest, but not significantly different, mortality. At Upper heights, most adults died at the exposed Site 6. Most adult mortality occurred at Low heights for Sites 1 to 4 . There were, however, no significant differences in settlement among heights for Site 4 where mortality decreased from Low to Mid to Upper heights. Greatest mortality was recorded at Upper heights at Site 6 (Table 3).

Generally, most adults and settlers were recorded low on the shore and least numbers of adult and juvenile barnacles were recorded at Upper heights at Cape Banks (Figs. 1 \& 2, Tables $1 \& 2$ ). Although most mortality of adults occurred at Low heights at Sites 1 to 4 (Table 3), this was not related to larger numbers of adults inhabiting these sites. There was no relationship between adult percentage mortality and initial density of adults $(\mathrm{r}=0.22, \mathrm{p}=0.11, \mathrm{n}=54)$, nor between adult percentage mortality and percent cover of adults $(r=0.04$, $\mathrm{p}=0.79, \mathrm{n}=54$ ) for all sites and heights from the end of 1989 to the end of 1992. Adult mortality was apparently density-independent.

Similarly, no relationship was found between percentage mortality of juveniles and cumulative density of settlers ( $\mathrm{r}=0.17, \mathrm{p}=0.1, \mathrm{n}=90)$, nor between percentage mortality of juveniles and percent cover of mixed cohorts $(r=0.02, p=0.88, n=90)$ for each period of settlement from July to December of 1989 to 1993 for all sites and heights. Juvenile mortality was also density-independent and spatial patterns of mortality did

Table 3. Chamaesipho tasmanica. Analysis of annual percentage mortality of mixed cohorts of adult barnacles $(n=3)$ at Low, Mid and Upper heights of C. tasmanica's distribution on the shore at 6 sites: annual adult mortality was estimated at the end of each year from 1990 to 1992 as a percentage of adults lost from the initial population recorded 12 mo previously. Analyses were performed on annual percentage mortality $(\mathrm{n}=3)$ for 3 yr from 1990 to $1992 . \mathrm{ns}$ : $\mathrm{p}>0.05_{;}{ }^{*} \mathrm{p}<0.05_{\text {; }}$ ${ }^{* *} \mathrm{p}<0.01 ;{ }^{* * *} \mathrm{p}<0.001$

\begin{tabular}{|lcrcc|}
\hline \multicolumn{5}{l}{$\begin{array}{l}\text { Analysis of variance, data-transformed; } \\
\text { Cochran's test, } \mathrm{p}>0.05\end{array}$} \\
Source & df & MS & $F$ & $\mathrm{p}$ \\
\hline Time $=\mathrm{T}$ & 2 & 79.37 & 0.15 & $\mathrm{~ns}$ \\
Site $=\mathrm{S}$ & 5 & 596.94 & 3.60 & ${ }^{* *}$ \\
$\mathrm{Height}=\mathrm{H}$ & 2 & 686.88 & 0.80 & $\mathrm{~ns}$ \\
$\mathrm{~T} \times \mathrm{S}$ & 10 & 533.64 & 3.22 & ${ }^{* *}$ \\
$\mathrm{~T} \times \mathrm{H}$ & 4 & 79.52 & 0.75 & $\mathrm{~ns}$ \\
$\mathrm{~S} \times \mathrm{H}$ & 10 & 853.99 & 5.16 & ${ }^{* * *}$ \\
$\mathrm{~T} \times \mathrm{S} \times \mathrm{H}$ & 20 & 105.68 & 0.64 & $\mathrm{~ns}$ \\
Residual & 108 & 165.62 & & \\
\hline
\end{tabular}


not reflect spatial patterns of settlement (total settlers: Site $3=4>5=2>1>6$; settler \% mortality: Site $4>6=$ $3=1>2=5$ ) (Tables $2 \& 4)$.

Analysis of variance showed that mortality of juveniles from 1989 to 1993 varied both temporally and spatially and that there were interactions among Times and Sites (Table 4). There was no significant difference in percentage mortality of juveniles among heights ( $\mathrm{r}=0.04, \mathrm{p}=0.71, \mathrm{n}=90$; Table 4). Generally, the greatest proportion of settlers died at sheltered Site 4 and the least at exposed Sites 2 and 5 (Table 4). At all sites (except Site 4 when mortality was highest in 1990), greatest mortality occurred in 1991. Otherwise no general temporal patterns of settler mortality were recorded among sites. When settler data for heights were pooled for each site, relationships were evident between total numbers of barnacles that settled at each site from July to December each year and the total numbers of these barnacles that remained in December each year from 1989 to 1993 (Fig. 6).

Data from 1990 to 1992 were analyzed to compare patterns of juvenile and adult mortality: mortality of
Table 4. Chamaesipho tasmanica. Analysis of percentage mortality of total settlers $(n=3)$ at Low, Mid and Upper heights of $C$. tasmanica's distribution on the shore at 6 sites: juvenile percentage mortality was estimated on cumulative settlement from August to December each year from 1989 to 1993. Arcsine (\%) transformation could not stabilize the variances: Cochran's test, $C=0.13, \mathrm{p}<0.01$. ns: $\mathrm{p}>0.05$; ${ }^{*} \mathrm{p}<0.05 ;{ }^{* *} \mathrm{p}<0.01 ;{ }^{* * *} \mathrm{p}<0.001$

\begin{tabular}{|lrrrr|}
\hline \multicolumn{5}{l}{$\begin{array}{l}\text { Analysis of variance, data-transformed; } \\
\text { Cochran's test, } C=0.10, \mathrm{p}<0.05\end{array}$} \\
Source & df & MS & $F$ & $\mathrm{p}$ \\
\hline Time $=\mathrm{T}$ & 4 & 13016.12 & 7.42 & $* * *$ \\
Site $=\mathrm{S}$ & 5 & 4367.14 & 15.34 & $* * *$ \\
$\mathrm{Height}=\mathrm{H}$ & 2 & 942.78 & 2.51 & $\mathrm{~ns}$ \\
$\mathrm{~T} \times \mathrm{S}$ & 20 & 1754.76 & 6.17 & $* *$ \\
$\mathrm{~T} \times \mathrm{H}$ & 8 & 750.85 & 1.81 & $\mathrm{~ns}$ \\
$\mathrm{~S} \times \mathrm{H}$ & 10 & 374.99 & 1.32 & $\mathrm{~ns}$ \\
$\mathrm{~T} \times \mathrm{S} \times \mathrm{H}$ & 40 & 413.76 & 1.45 & $\mathrm{~ns}$ \\
Residual & 180 & 284.62 & & \\
\hline
\end{tabular}

juveniles was found to be greater than that of adults at Low, Mid and Upper heights (Fig. 5) of Sites 1 to 6 from 1990 to 1992 , except in 1992 at Site 3 (Table 5), when percentage mortality of juveniles and adults was similar (percentage mortality of juveniles in 1992 at Site 3 was, however, marginally, but not significantly, greater than that of adults) (Table 5). While there were no consistent temporal patterns, generally more juvenile and adult mortality were recorded in 1991 at the 3 heights and 6 sites. From 1990 to 1992, greatest mortality of juveniles was recorded at Site 4 (Fig. 5), whereas greatest mortality of adults was at Sites 3 and 6 (Fig. 5) in 1991 and Sites 3 and 5 in 1992. In 1990, there was no significant difference in percentage mortality of adults among sites although Site 2 had the largest adult mortality. In 1992, greatest juvenile mortality was recorded at Low heights. From 1990 to 1992, most adult mortality was recorded at Low heights, which was only significantly greater than Mid and Upper heights in 1990 (Fig. 5, Table 5).

\section{Effect of Cellana tramoserica}

Temporal and spatial variation in recruitment occurred before and after the limpet Cellana tramoserica was
Fig. 6. Chamaesipho tasmanica. Relationship between final number of settlers surviving and total numbers of barnacles settling each year at 3 heights at the 6 sites from the end of 1989 to the end of 1993. Each point represents total numbers of settlers recorded in each $6 \mathrm{~cm}$ replicate $(\mathrm{n}=3)$ 
added to or excluded from Fenced and Unfenced plots on 14 November 1990 and 18 November 1991 (Fig. 7). When data on the effects of $C$. tramoserica on postsettlement mortality of Chamaesipho tasmanica were analyzed, there were shown to be interactions among Times and Sites and \pm C. tramoserica (Fig. 8, Table 6a). Greater mortality occurred from 14 November to 27 December 1990 than from 18 November 1991 to 6 January 1992 at both Sites 3 and 4 and in all $\pm C$. tramoserica treatments (Fig. 8, Table 6a). At neither time was there a difference in post-settlement mortality among sites. At Site 3, by 27 December 1990, there was no significant difference in mortality between those replicates that had limpets nor those from which limpets were excluded. At Site 4, however, greater mortality occurred where C. tramoserica was present. By 6 January 1992, greater mortality was recorded where limpets were present (Table 6a).

There was no significant difference in mortality between Fenced and Unfenced plots (Fig. 8, Table 6a). Hence data for \pm Fences were pooled (Table $6 \mathrm{~b}$ ) and analyses of data showed that a greater percentage of barnacles had died by 27 December 1990 than by 6 January 1992. This greater mortality always occurred when limpets were present. Cellana tramoserica was therefore responsible for post-settlement mortality of Chamaesipho tasmanica at sheltered Sites 3 and 4 at Cape Banks.
Table 5. Chamaesipho tasmanica. Analysis of annual percentage mortality of mixed cohorts of adult versus percentage mortality of juvenile barnacles $(n=3)$ at Low, Mid and Upper heights of $C$. tasmanica's distribution on the shore at 6 sites: annual adult mortality was estimated at the end of each year as a percentage of adults lost from the initial population recorded 12 mo previously. Juvenile percentage mortality was estimated on cumulative settlement from August to December each year. Analyses were performed on juvenile versus adult percentage mortality $(\mathrm{n}=3$ ) for $3 \mathrm{yr}$ from 1990 to 1992. Arcsine (\%) transformation could not stabilize the variances: Cochran's test, $C=0.19, \mathrm{p}<0.01$. ns: $\mathrm{p}>0.05$. ${ }^{*} \mathrm{p}<0.05 ;{ }^{* *} \mathrm{p}<0.01 ;{ }^{* * *} \mathrm{p}<0.001$

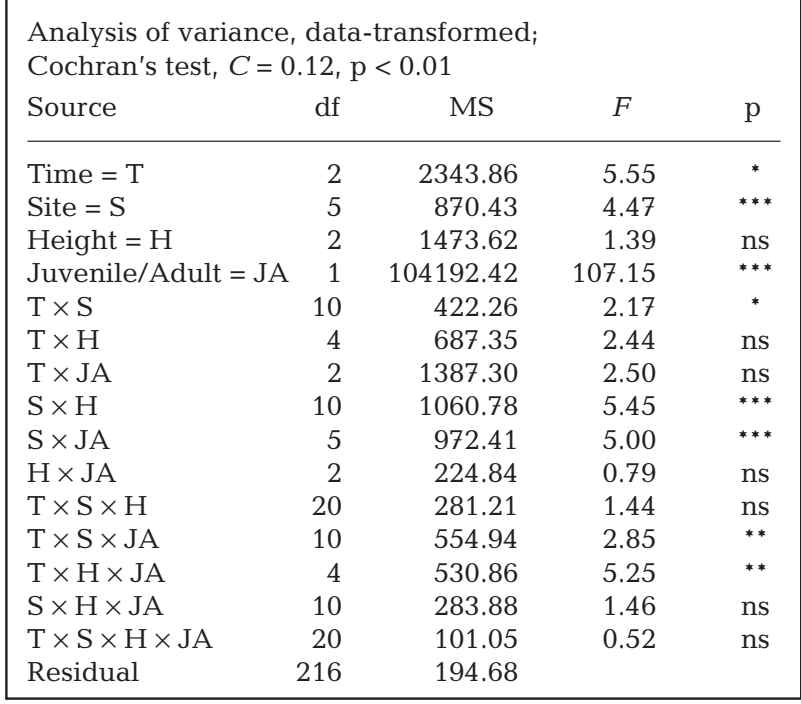

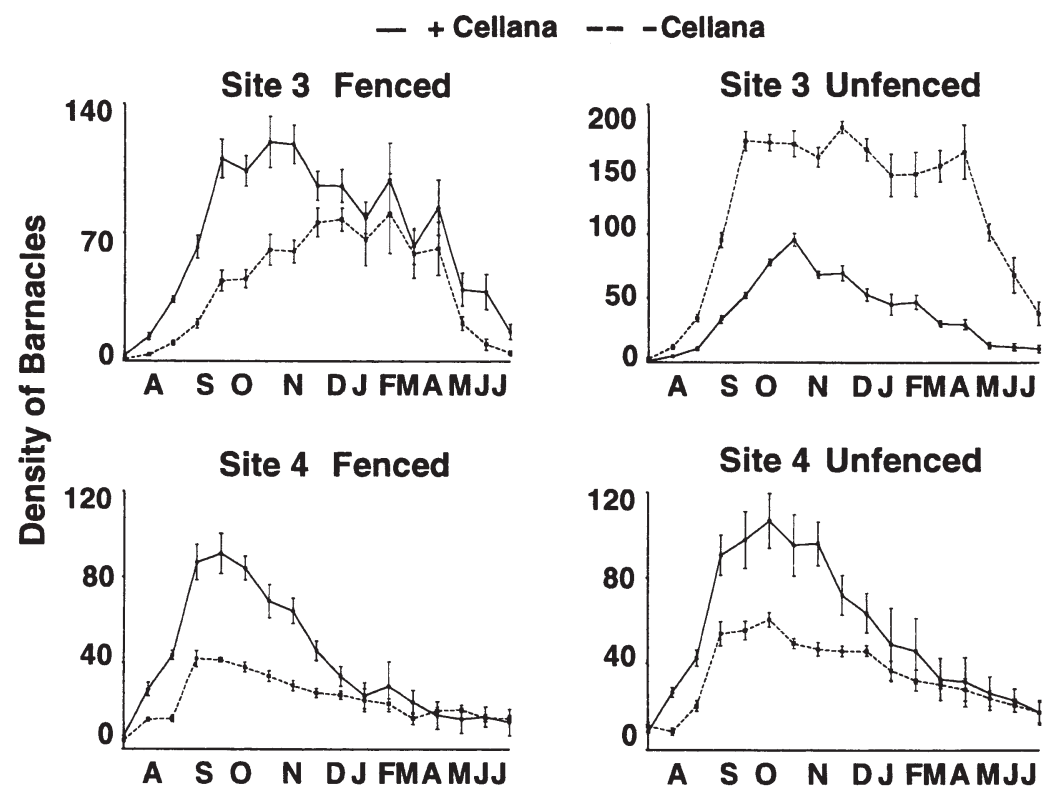

Fig. 7. Mean number of barnacles $( \pm \mathrm{SE})$ recorded per 6 to $8 \mathrm{~d}$ sampling period from July 1991 to early July 1992 at Sites 3 and 4 in plots \pm Cellana tramoserica and \pm fences $(\mathrm{n}=4)$. C. tramoserica and fences were added, where appropriate, on 18 November 1991. Note that some minor settlement occurred from January to March 1992, and note the effect of predation by Morula marginalba on all treatments in Site 3 from April to July 1992
The predatory whelk Morula marginalba was also responsible for a sudden increase in mortality of Chamaesipho tasmanica in all treatments at Site 3 from April to July 1992 (Fig. 7).

\section{DISCUSSION}

Many previous studies have emphasized adult interactions as determinants of demography of barnacles (Connell 1961a,b, Dayton 1971, Paine 1974). Some early studies, however, recognized the implications of variation in settlement for populations of sessile adults (Barnes \& Powell 1950, Barnes 1956). More recently, the importance of variable settlement and recruitment of juveniles has been confirmed in processes determining populations of adults (e.g. Hawkins \& Hartnoll 1982, Underwood et al. 1983, Caffey 1985, Fairweather 1988a, Pineda 1994). The earlier ecological 


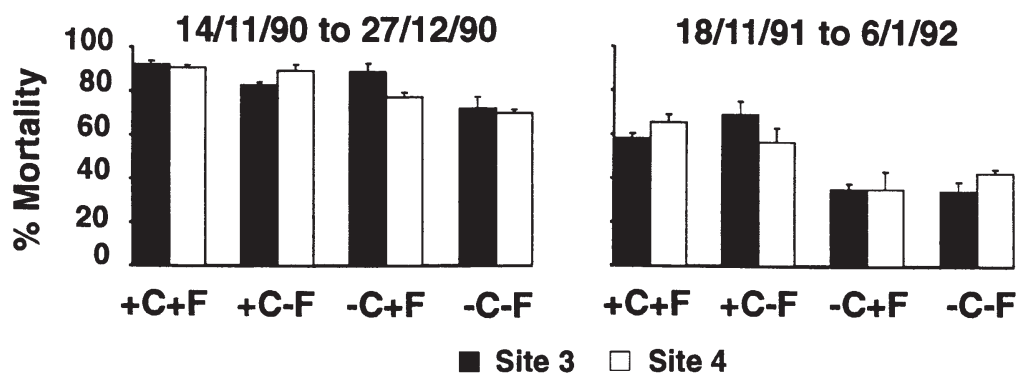

Fig. 8. Post-settlement mortality of barnacles $( \pm$ SE) from 14 November 1990 to 27 December 1990 and from 18 November 1991 to 6 January 1992. Cellana tramoserica and fences were added to or excluded from plots $(n=4)$ on 14 November 1990 and 18 November 1991, respectively, when most settlement had occurred. $\pm \mathrm{C}= \pm$ Cellana; $\pm \mathrm{F}= \pm$ Fences influences on patterns of distribution of Chamaesipho tasmanica. For example, at Site 3 Low from April to July 1992, when many replicates contained $50 \%$ empty shells and the whelk Morula marginalba was observed feeding on barnacles. Only at Site 3 Low were there plenty of crevices, which is consistent with the relationship between availability of crevices and predation (Fairweather et al. 1984, Moran 1985, Fairweather 1988b,c, Johnson et al. 1998). Predation may therefore maintain the uniform small size of C. tasmanica char- theory was based on species with abundant larval supply and space limitation when settling (Southward \& Crisp 1954, 1956, Connell 1961a,b, Gaines \& Roughgarden 1985, Roughgarden et al. 1985, 1988). Today, it is accepted that other processes operate when numbers of larvae arriving are relatively few (Hawkins \& Hartnoll 1982, Roughgarden et al. 1985, 1987, 1988, Menge \& Sutherland 1987). In fact, if larval settlement is sparse, competition, predation and disturbance can have no influence on population abundance and distribution (Paine 1974, Underwood \& Denley 1984, Sutherland \& Ortega 1986).

The honeycomb barnacle Chamaesipho tasmanica in New South Wales has poor larval supply, and numbers of larvae arriving influence distributions of juveniles (Jeffery 2000, Jeffery \& Underwood 2000). Hence, this study was initiated to test the hypotheses from the models that settlement and/or post-settlement mortality of juveniles and of adults determine distributions of adults.

\section{Abundance and distribution}

The largest numbers of juvenile and adult barnacles were recorded at sheltered Sites 3 and 4 and at Low heights, whereas the smallest numbers occurred at exposed Site 6 and at Upper heights. Numbers of already established adults were found to decrease progressively from late 1989 to late 1993 because recruitment each year was generally not enough to maintain population numbers. Because the spatial patterns of settlers were the same as adults, and because spatial patterns of juvenile and adult mortality did not match spatial patterns of juveniles and adults, settlement was found to be more important than post-settlement mortality in determining the abundances and distributions of Chamaesipho tasmanica.

There may be, however, unusual circumstances where isolated incidences of adult mortality will have localized
Table 6. Chamaesipho tasmanica. Analysis of post-settlement mortality of juvenile barnacles $(n=4)$ at Low heights of $C$. tasmanica's distribution on the shore at Sites 3 and 4 . Post-settlement mortality was estimated over 6 wk after major settlement had occurred and after plots were manipulated for \pm Cellana and \pm Fences, from 14 November 1990 to 27 December 1990 and from 18 November 1991 to 6 January 1992. Postsettlement mortality was estimated as percentage mortality of new settlers and already established juveniles for each $6 \mathrm{wk}$ period. ns: $\mathrm{p}>0.05 ;{ }^{*} \mathrm{p}<0.05 ;{ }^{* *} \mathrm{p}<0.01 ;{ }^{* * *} \mathrm{p}<0.001$

\begin{tabular}{|c|c|c|c|c|}
\hline Source & $\mathrm{df}$ & MS & $F$ & $\mathrm{p}$ \\
\hline Time $=\mathrm{T}$ & 1 & 17502.55 & 508.67 & $*$ \\
\hline Site $=\mathrm{S}$ & 1 & 6.91 & 0.11 & ns \\
\hline \pm Cellana $=C$ & 1 & 5469.39 & 750.84 & $*$ \\
\hline \pm Fences $=\mathrm{F}$ & 1 & 165.51 & 21.13 & ns \\
\hline $\mathrm{T} \times \mathrm{S}$ & 1 & 34.41 & 0.56 & ns \\
\hline $\mathrm{T} \times C$ & 1 & 746.30 & 2.92 & ns \\
\hline $\mathrm{T} \times \mathrm{F}$ & 1 & 469.85 & 2.31 & ns \\
\hline $\mathrm{S} \times C$ & 1 & 7.28 & 0.12 & ns \\
\hline $\mathrm{S} \times \mathrm{F}$ & 1 & 7.83 & 0.13 & ns \\
\hline$C \times \mathrm{F}$ & 1 & 21.70 & 0.10 & ns \\
\hline $\mathrm{T} \times \mathrm{S} \times C$ & 1 & 255.83 & 4.13 & $*$ \\
\hline $\mathrm{T} \times \mathrm{S} \times \mathrm{F}$ & 1 & 203.04 & 3.28 & ns \\
\hline $\mathrm{T} \times C \times \mathrm{F}$ & 1 & 77.49 & 0.45 & ns \\
\hline $\mathrm{S} \times C \times \mathrm{F}$ & 1 & 218.92 & 3.54 & ns \\
\hline $\mathrm{T} \times \mathrm{S} \times C \times \mathrm{F}$ & 1 & 173.12 & 2.80 & ns \\
\hline Residual & 48 & 61.92 & & \\
\hline \multicolumn{5}{|c|}{$\begin{array}{l}\text { (b) Analysis of variance, } \pm \text { Fences pooled, data-untransformed; } \\
\text { Cochran's test, } p>0.05\end{array}$} \\
\hline Source & $\mathrm{df}$ & MS & $F$ & $\mathrm{p}$ \\
\hline Time $=\mathrm{T}$ & 1 & 17502.55 & 508.67 & * \\
\hline Site $=\mathrm{S}$ & 1 & 6.91 & 0.09 & ns \\
\hline \pm Cellana $=C$ & 1 & 5469.39 & 750.84 & $*$ \\
\hline $\mathrm{T} \times \mathrm{S}$ & 1 & 34.41 & 0.45 & ns \\
\hline $\mathrm{T} \times C$ & 1 & 746.30 & 2.92 & ns \\
\hline $\mathrm{S} \times C$ & 1 & 7.28 & 0.09 & ns \\
\hline $\mathrm{T} \times \mathrm{S} \times C$ & 1 & 255.83 & 3.32 & ns \\
\hline Residual & 56 & 76.96 & & \\
\hline
\end{tabular}


acteristic of Site 3 Low and determine adult patterns even though large numbers of larvae initially settled and recruited. Hence, where the habitat is suitable for predators, post-settlement mortality may be more important than initial settlement for the demography of $C$. tasmanica. Similarly, Connell (1970) found that on lowshore areas at San Juan Island, where predation was great, populations of the barnacle Balanus glandula were diminished.

Moreover, Site 6 was characterized by progressively decreasing numbers of barnacles from low to mid to upper heights within distributions of Chamaesipho tasmanica as distance up the shore increased. It may be that differential larval supply and recruitment determine these differences in demography in this area. Early studies on barnacles, however, showed that physical factors such as temperature and desiccation determined the upper limits of vertical distribution and influenced population densities (Connell 1961a,b, 1975). In this study, there was greatest mortality of adult C. tasmanica on upper shores at Site 6. Here, mortality may override the process of larval supply to influence numbers of barnacles. An investigation into larval supply on exposed shores is therefore warranted.

\section{Post-settlement mortality and adult distribution}

\section{Juvenile and adult mortality}

Simultaneous studies have shown that initial settlement (larval supply and larval choice) determines juvenile distributions of Chamaesipho tasmanica at Cape Banks (Jeffery 2000, Jeffery \& Underwood 2000). This corroborates Denley \& Underwood's (1979) findings on Tesseropora rosea. When they studied newly settled barnacles, they found that mechanisms of settlement, not post-settlement mortality, determined the upper limits of distribution. Results from this study emphasize that settlement, not post-settlement, processes (except in particular circumstances such as when the predatory whelk Morula marginalba was present at Site 3 Low) determine adult spatial patterns of distribution of $C$. tasmanica. Temporal and spatial variations in adult populations were inconsistent with adult or juvenile mortality. In fact, populations of C. tasmanica decreased generally at all sites and heights at Cape Banks from 1989 to 1993, and this was because the numbers that recruited each year generally were not sufficient to balance the numbers lost. It may be then that in years when settlement and recruitment are negligible, mortality of adults will determine their spatial distribution. Despite this, densities of juveniles and adults varied spatially at Cape Banks, but spatial patterns of mortality did not match the juvenile and adult patterns. This is contrary to the model that fewer adult barnacles exist on exposed and upper shores as a function of greater mortality in these areas. Settlement, rather than mortality, is therefore highlighted here as a determinant of distributions of populations of adult barnacles.

Bertness (1989) showed that intense recruitment actually enhanced survival of the barnacle Semibalanus balanoides in more exposed areas by providing a buffer against physical stresses. Because Chamaesipho tasmanica was found to exhibit density-independent mortality and because many large barnacles were found on upper heights (Jeffery \& Underwood 2001), mortality of adults may decrease once barnacles are established. This is contrary to Connell's (1961a,b, 1975) findings that extreme physical conditions determined the upper limits of vertical distribution and influenced population densities by increasing mortality on upper exposed shores. In fact, Fairweather et al. (1984) found that survival of C. tasmanica increased with increasing height on the shore regardless of the presence or absence of Morula marginalba. It may be that physical stresses influence settlers (with larger surface:area volume ratios) more than adults on upper shores. In this study, however, most mortality occurred low on the shore at Site 3 and on Upper heights at Site 6. It seems that site-specific characteristics (Hawkins \& Hartnoll 1982) may be implicated in determining these differences in mortality in these areas.

Juvenile mortality at the 6 sites was densityindependent. Spatial patterns of settlers and adults were similar and did not reflect juvenile or adult mortality patterns. Post-settlement mortality did not therefore determine adult populations of Chamaesipho tasmanica. Also, because both juvenile and adult mortality of $C$. tasmanica were found to be densityindependent at Cape Banks, this study supports Connell's (1985) statement that settlement determines adult densities when juvenile or adult mortality of barnacles is density-independent.

Even though percentage mortality of juveniles was estimated only for the period of settlement from July to December of each year, whereas adult percentage mortality was an annual estimation, juvenile mortality was still found to be much greater than adult mortality. This difference in juvenile and adult mortality at the 6 sites suggests that different mechanisms are operating to influence mortality at different stages of the life cycle of Chamaesipho tasmanica and that juveniles are more 'fragile' than established adults.

\section{Effect of Cellana tramoserica}

Juvenile populations of Chamaesipho tasmanica at Sites 3 and 4 were modified by the presence of the 
limpet Cellana tramoserica; however, results do not suggest that this effect was sufficient to carry through to adult populations. C. tramoserica occurs in patches of free space among C. tasmanica and was found to affect numbers of juveniles that occupied these spaces. C. tramoserica possesses a radula with a few large teeth in each row, which enables the limpet to forage for diatoms and algal spores among cracks in the substratum (Underwood 1975, 1978). This could explain its influence on survival of young barnacles. Analysis of pooled fenced and unfenced data demonstrated that the presence of $C$. tramoserica had a deleterious effect on survival of young C. tasmanica. Greater mortality of new settlers of barnacles occurred when limpets were present, but there was no significant difference in mortality when fences were present or absent. This indicates that there were no fence effects on recruitment (Underwood \& Jernakoff 1984, Hancock \& Petraitis 2001), and that other grazers that may have unaccountably wandered into unfenced plots either had no effect on young $C$. tasmanica or that $C$. tramoserica densities in experimental plots were high enough to swamp the effect of other grazers on juvenile populations of barnacles.

Cellana tramoserica does not affect adult populations of Tesseropora rosea (Denley \& Underwood 1979, Denley 1981, Underwood et al. 1983). Therefore, $C$. tramoserica was not thought to cause mortality in adult populations of Chamaesipho tasmanica. Because this study has also shown that spatial patterns of adults were the same as those of settlers, it is assumed that $C$. tramoserica can only affect distributions of early juveniles and, once new barnacles establish, the influence of C. tramoserica is reduced.

\section{Settlement versus post-settlement mortality}

Although juvenile mortality was much greater than adult mortality at the 6 sites, the spatial patterns of settlement of juveniles (Site $3=4>5=2>1>6$ ) reflected adult patterns (Site $3=4>5=2=1>6$ ). That is, despite great post-settlement mortality of settlers, juvenile patterns were retained in the adult stage. At the 6 sites, relationships were also found between total numbers of barnacles that settled each year and the numbers of these settlers that remained at the end of each year from 1989 to 1993. Moreover, when data were pooled for the 6 sites and 3 heights from 1989 to 1993, there was a strong relationship between total annual density of settlers and total annual density of adults. Therefore, settlement, not post-settlement mortality, is paramount in determining spatial abundance and distributions of populations of Chamaesipho tasmanica.

\section{CONCLUSIONS}

Historically, post-settlement mortality was implicated in determining sizes of barnacle populations (Connell 1985). Otaiza (1989) suggested that spatial abundance and distribution of Chamaesipho tasmanica at Cape Banks in 1986 and 1987 were determined by differences in total recruitment, survival or both. This study found that settlement determined the ultimate distributions of adult C. tasmanica at Cape Banks. The alternative model that post-settlement mortality determined the distributions and abundance of juveniles and adults was not supported by experiments. Despite great post-settlement mortality of juveniles, especially when the limpet Cellana tramoserica was present, spatial patterns of settlers and adults were similar and were not altered by juvenile or adult mortality. That is, juvenile spatial patterns were mirrored by adult patterns, but not by spatial patterns of juvenile or adult mortality. Post-settlement mortality was therefore rejected as a model for causing the sparse populations of barnacles on exposed and upper shores.

Because relatively few cyprid larvae of Chamaesipho tasmanica arrive to settle (Jeffery \& Underwood 2000), this study confirms the recently proposed model that sparse recruitment will determine that patterns of adult numbers will match patterns of numbers of recruits (Connell 1985, Carroll 1996). Earlier models on settlement and survivorship pertained to those species with unlimited larval supply, but limited space for these larvae to settle (Southward \& Crisp 1954, 1956, Barnes 1956, Connell 1961a,b, 1985). Gaines \& Roughgarden (1985) extended these ideas to include models that incorporated variable (small to large) settlement with space-limited recruitment. They postulated that populations with steady-state abundance were derived from small rates of settlement, whereas temporally oscillating populations were derived from large rates of settlement.

Like Chamaesipho tasmanica, the intertidal barnacle Chthamalus fissus on tropical rocky shores in Costa Rica is characterized by poor larval supply and abundant space for settling cyprids (Sutherland 1990), but predation by fish and gastropods maintains space (Sutherland \& Ortega 1986). In the northern hemisphere, patterns of assemblages are influenced by predation by the seastar Pisaster ochraceus (Paine 1974, 1984), but there is no similar major predator in Australia. Whelks are also important predators in the United States (Dayton 1971, Menge 1976, Lubchenco \& Menge 1978) and very much so in New South Wales (Underwood 1994). In fact, predation in Australia is complex with different patterns exhibited in different areas with similar species (Underwood \& Fairweather 
1986, Underwood 1994). Australian research, however, implies that predation may be minor compared with the effects of recruitment on diversity of populations (Underwood et al. 1983). While this study has highlighted the importance of larval processes in determining numbers of C. tasmanica at Cape Banks, mortality, especially predation by whelks, appears to play a secondary role.

In summary, while this study showed that numbers of Chamaesipho tasmanica noticeably decreased from 1989 to 1993 at Cape Banks, it has emphasized that the number of larvae that settle is crucial to the formation of spatial patterns of juvenile and adult barnacles. Other studies have shown that larval supply of $C$. tasmanica depends on a concordance of numerous processes, but larvae can be supplied in a consistent pattern on sheltered shores at Cape Banks (Jeffery \& Underwood 2000). Hence, longer-term ecological studies of larval supply, settlement and recruitment of $C$. tasmanica at various sites and shores on the eastern Australian coast are necessary to determine processes governing patterns of variation of this barnacle at larger spatial scales. Effects of site-specific characteristics on larval supply (Jeffery \& Underwood 2000), settlement (Jeffery 2000, Jeffery \& Underwood 2000) and longevity after settlement (Jeffery \& Underwood 2001) will probably then become even more apparent as major causative mechanisms for the demography of C. tasmanica.

Acknowledgements. This research was part of my PhD thesis at the University of Sydney and was financed by the University Research Grants, funds from the Institute of Marine Ecology at the University of Sydney and an Australian Museum Postgraduate Grant. Many thanks are due to Tony Underwood for his support throughout this study.

\section{LITERATURE CITED}

Barnes H (1956) Balanus balanoides (L.) in the Firth of Clyde: the development and annual variation of the larval population, and the causative factors. J Anim Ecol 25:72-84

Barnes H, Powell HT (1950) The development, general morphology and subsequent elimination of barnacle populations, Balanus crenatus and B. balanoides, after a heavy initial settlement. J Anim Ecol 19:175-179

Bertness MD (1989) Intraspecific competition and facilitation in a northern acorn barnacle population. Ecology 70: $257-268$

Branch GM (1981) The biology of limpets: physical factors, energy flow, and ecological interactions. Oceanogr Mar Biol Annu Rev 19:235-380

Brown AC (1967) Desiccation as a factor influencing the vertical distribution of some South African gastropoda from intertidal rocky shores. Port Acta Biol Ser B 7:11-23

Caffey HM (1983) The partitioning of spatial and temporal variation in settlement and recruitment of the intertidal barnacle, Tesseropora rosea. $\mathrm{PhD}$ thesis, University of Sydney

Caffey HM (1985) Spatial and temporal variation in settle- ment and recruitment of intertidal barnacles. Ecol Monogr 55:313-332

Carroll ML (1996) Barnacle population dynamics and recruitment regulation in southcentral Alaska. J Exp Mar Biol Ecol 199:285-302

Connell JH (1961a) The influence of interspecific competition and other factors on the distribution of the barnacle Chthamalus stellatus. Ecology 42:710-723

Connell JH (1961b) The effects of competition, predation by Thais lapillus and other factors on natural populations of the barnacle Balanus balanoides. Ecol Monogr 31:61-104

Connell JH (1970) A predator-prey system in the marine intertidal region. I. Balanus glandula and several predatory species of Thais. Ecol Monogr 40:49-78

Connell JH (1972) Community interactions on marine rocky intertidal shores. Annu Rev Ecol Syst 3:169-192

Connell JH (1975) Some mechanisms producing structure in natural communities: a model and evidence from field experiments. In: Cody ML, Diamond JM (eds) Ecology and evolution of communities. Belknap Press, Cambridge, p 460-490

Connell JH (1985) The consequences of variation in initial settlement vs. post-settlement mortality in rocky intertidal communities. J Exp Mar Biol Ecol 93:11-45

Dayton PK (1971) Competition, disturbance, and community organization: the provision and subsequent utilization of space in a rocky intertidal community. Ecol Monogr 41: 351-389

Denley EJ (1981) The ecology of the intertidal barnacle, Tesseropora rosea. PhD thesis, University of Sydney

Denley EJ, Underwood AJ (1979) Experiments on factors influencing settlement, survival, and growth of two species of barnacles in New South Wales. J Exp Mar Biol Ecol 36:269-273

Fairweather PG (1988a) Consequences of supply-side ecology: manipulating the recruitment of intertidal barnacles affects the intensity of predation upon them. Biol Bull 175: 349-354

Fairweather PG (1988b) Movements of intertidal whelks (Morula marginalba and Thais orbita) in relation to availability of prey and shelter. Mar Biol 100:63-68

Fairweather PG (1988c) Predation creates haloes of bare space among prey on rocky seashores in New South Wales. Aust J Ecol 13:401-409

Fairweather PG, Underwood AJ, Moran MJ (1984) Preliminary investigations of predation by the whelk Morula marginalba Blainville. Mar Ecol Prog Ser 17:143-156

Farrell TM (1988) Community stability: effects of limpet removal and reintroduction in a rocky intertidal community. Oecologia 75:190-197

Gaines S, Roughgarden J (1985) Larval settlement rate: a leading determinant of structure in an ecological community of the marine intertidal zone. Proc Natl Acad Sci 82: 3707-3711

Grosberg RK (1982) Intertidal zonation of barnacles: the influence of planktonic zonation of larvae on vertical distribution of adults. Ecology 63:894-899

Hancock KM, Petraitis PS (2001) Effects of herbivorous snails and macroalgal canopy on recruitment and early survivorship of the barnacle Semibalanus balanoides (L.). J Exp Mar Biol Ecol 257:205-218

Hawkins SJ, Hartnoll RG (1982) Settlement patterns of Semibalanus balanoides (L.) in the Isle of Man (1977-1981). J Exp Mar Biol Ecol 62:271-283

Hunt HL, Scheibling RE (1997) Role of early post-settlement mortality in recruitment of benthic marine invertebrates. Mar Ecol Prog Ser 155:269-301 
Jeffery CJ (1997) The ecology of the rocky shore intertidal barnacle Chamaesipho tasmanica in New South Wales. $\mathrm{PhD}$ thesis, University of Sydney

Jeffery CJ (2000) Settlement in different-sized patches by the gregarious intertidal barnacle Chamaesipho tasmanica Foster and Anderson in New South Wales. J Exp Mar Biol Ecol 252:15-26

Jeffery CJ, Underwood AJ (2000) Consistent spatial patterns of arrival of larvae of the honeycomb barnacle Chamaesipho tasmanica Foster and Anderson in New South Wales. J Exp Mar Biol Ecol 252:109-127

Jeffery CJ, Underwood AJ (2001) Longevity determines sizes of an adult intertidal barnacle. J Exp Mar Biol Ecol 256: 85-97

Jenkins SR, Åberg P, Cervin G, Coleman RA and 10 others (2000) Spatial and temporal variation in settlement and recruitment of the intertidal barnacle Semibalanus balanoides (L.) (Crustacea: Cirripedia) over a European scale. J Exp Mar Biol Ecol 243:209-225

Johnson MP, Hughes RN, Burrows MT, Hawkins SJ (1998) Beyond the predation halo: small scale gradients in barnacle populations affected by the relative refuge value of crevices. J Exp Mar Biol Ecol 231:163-170

Lubchenco J (1978) Plant species diversity in a marine intertidal community: importance of herbivore food preference and algal competitive abilities. Am Nat 112:23-39

Lubchenco J (1980) Algal zonation in the New England rocky intertidal community: an experimental analysis. Ecology 61:333-344

Lubchenco J, Menge BA (1978) Community development and persistence in a low rocky intertidal zone. Ecol Monogr 48: 67-94

Mackay DA, Underwood AJ (1977) Experimental studies on homing in the intertidal Patellid limpet Cellana tramoserica (Sowerby). Oecologia 30:215-237

Menge BA (1976) Organization of the New England rocky intertidal community: role of predation, competition, and environmental heterogeneity. Ecol Monogr 46: 355-393

Menge BA (2000) Recruitment vs. postrecruitment processes as determinants of barnacle population abundance. Ecol Monogr 70:265-288

Menge BA, Lubchenco J (1981) Community organization in temperate and tropical rocky intertidal habitats: prey refuges in relation to consumer pressure gradients. Ecol Monogr 51:429-450

Menge BA, Sutherland JP (1976) Species diversity gradients: synthesis of the roles of predation, competition, and temporal heterogeneity. Am Nat 110:351-369

Menge BA, Sutherland JP (1987) Community regulation: variation in disturbance, competition, and predation in relation to environmental stress and recruitment. Am Nat 130: $730-757$

Minchinton TE, Scheibling RE (1991) The influence of larval supply and settlement on the population structure of barnacles. Ecology 72:1867-1879

Miron G, Boudreau B, Bourget E (1999) Intertidal barnacle distributions: a case study using multiple working hypotheses. Mar Ecol Prog Ser 189:205-219

Moran MJ (1985) The timing and significance of sheltering and foraging behaviour of the predatory intertidal gastropod Morula marginalba Blainville (Muricidae). J Exp Mar Biol Ecol 93:103-114

Olivier F, Tremblay R, Bourget E, Rittschof D (2000) Barnacle settlement: field experiments on the influence of larval supply, tidal level, biofilm quality and age on Balanus amphitrite cyprids. Mar Ecol Prog Ser 199:185-204
Otaiza RD (1989) Arrival and recruitment of intertidal barnacles on rocky shores in central New South Wales, Australia. PhD thesis, University of Sydney

Paine RT (1966) Food web complexity and species diversity. Am Nat 100:65-75

Paine RT (1969) The Pisaster-Tegula interaction: prey patches, predator food preference, and intertidal community structure. Ecology 50:950-961

Paine RT (1974) Intertidal community structure: experimental studies on the relationship between a dominant competitor and its principal predator. Oecologia 15:93-120

Paine RT (1984) Ecological determinism in the competition for space. Ecology 65:1339-1348

Pineda J (1994) Spatial and temporal patterns in barnacle settlement rate along a southern California rocky shore. Mar Ecol Prog Ser 107:125-138

Raimondi PT (1991) Settlement behavior of Chthamalus anisopoma larvae largely determines the adult distribution. Oecologia 85:349-360

Ross PM (1992) The ecology of barnacles in temperate mangrove forests. PhD thesis, University of Sydney

Roughgarden J, Iwasa Y, Baxter C (1985) Demographic theory for an open marine population with space-limited recruitment. Ecology 66:54-67

Roughgarden J, Gaines SD, Pacala SW (1987) Supply side ecology: the role of physical transport processes. In: Gee JHR, Giller PS (eds) Organizations of communities past and present. Blackwell Scientific Publishers, London, p 491-518

Roughgarden J, Gaines S, Possingham H (1988) Recruitment dynamics in complex life cycles. Science 241: 1460-1466

Sousa WP (1979) Experimental investigations of disturbance and ecological succession in a rocky intertidal algal community. Ecol Monogr 49:227-254

Southward AJ, Crisp DJ (1954) Recent changes in the distribution of the intertidal barnacles Chthamalus stellatus Poli and Balanus balanoides L. in the British Isles. J Anim Ecol 23:163-177

Southward AJ, Crisp DJ (1956) Fluctuations in the distribution and abundance of intertidal barnacles. J Mar Biol Assoc UK 35:211-229

Sutherland JP (1990) Recruitment regulates demographic variation in a tropical intertidal barnacle. Ecology 71 : 955-972

Sutherland JP, Ortega S (1986) Competition conditional on recruitment and temporary escape from predators on a tropical rocky shore. J Exp Mar Biol Ecol 95:155-166

Underwood AJ (1975) Intertidal zonation of prosobranch gastropods: analysis of densities of four co-existing species. J Exp Mar Biol Ecol 19:197-216

Underwood AJ (1977) Movements of intertidal gastropods. J Exp Mar Biol Ecol 26:191-201

Underwood AJ (1978) An experimental evaluation of competition between three species of intertidal prosobranch gastropods. Oecologia 33:185-202

Underwood AJ (1979) The ecology of intertidal gastropods. Adv Mar Biol 16:111-210

Underwood AJ (1981a) Structure of a rocky intertidal community in New South Wales: patterns of vertical distribution and seasonal changes. J Exp Mar Biol Ecol 51: 57-85

Underwood AJ (1981b) Techniques of analysis of variance in experimental marine biology and ecology. Oceanogr Mar Biol Annu Rev 19:513-605

Underwood AJ (1988) Design and analysis of field experiments on competitive interactions affecting behaviour of 
intertidal animals. In: Chelazzi G, Vannini M (eds) Behavioural adaptation to intertidal life. Plenum Press, New York, p 333-358

Underwood AJ (1994) Rocky intertidal shores. In: Hammond LS, Synnot RN (eds) Marine biology. Longman-Cheshire, Melbourne, p 272-296

Underwood AJ (1997) Experiments in ecology: their logical design and interpretation using analysis of variance. Cambridge University Press, Cambridge

Underwood AJ, Denley EJ (1984) Paradigms, explanations, and generalizations in models for the structure of intertidal communities on rocky shores. In: Strong DR, Simberloff D, Abele LG, Thistle AB (eds) Ecological communities: conceptual issues and the evidence. Princeton University Press, Princeton, NJ, p 151-180

Editorial responsibility: Roger Hughes (Contributing Editor), Bangor, Wales, UK
Underwood AJ, Fairweather PG (1986) Intertidal communities: do they have different ecologies or different ecologists? Proc Ecol Soc Aust 14:7-16

Underwood AJ, Jernakoff P (1984) The effects of tidal height, wave exposure, seasonality and rock-pools on grazing and the distribution of intertidal macroalgae in New South Wales. J Exp Mar Biol Ecol 75:71-96

Underwood AJ, Denley EJ, Moran MJ (1983) Experimental analyses of the structure and dynamics of mid-shore rocky intertidal communities in New South Wales. Oecologia 56: 202-219

Valiela I (1984) Marine ecological processes. Springer-Verlag, New York

Vermeij GJ (1971) Temperature relationships of some tropical Pacific intertidal gastropods. Mar Biol 10:308-314

Submitted: June 1, 2001; Accepted: July 30, 2002

Proofs received from author(s): January 4, 2003 